\title{
CORRESPONDENCE.
}

1. The Tàj or Red $\mathrm{C}_{A P}$ of the Shī'ahs.

\author{
Dresden, \\ April 21, 1896.
}

Dear SIr, - Two days ago, while translating a Persian MS. entitled "Basātinn-us-Salāțin "-a history of the "Ādil Shāhi lkings of Bijāpur-I met the following passage, which occurs in the account of the reign of Isma' îl 'A'Adil Shāh, the second king of the dynasty :-

"He ordered all the soldiers in his army to wear on their heads the red $t \bar{a} j$ [cap] of twelve notches [tarak]; and whoever did not wear the täj was not allowed to come to the saläm [levée]. Moreover, in that reign it was impossible for anyone to go to and fro in the city without the täj. If anyone chanced to be seen without a täj he was punished by the King. This custom continued to the end of the reign of Isma'îl Shäh."

It was a curious coincidence that the very day after translating this passage I received my copy of the Journal of the Royal Asiatic Society for April, and in Dr. Denison Ross' paper on "The Early Years of Shāh Isma'īl," I read on pp. 254-5 what appears to be the traditionary account of the origin of the red caps mentioned above.

I have in my possession a small history of the 'A dil Shāhī dynasty, entitled "Guldastah-i-Bijāpur," which gives a likeness of each of the kings, and Isma'îl "Ādil Shāh is represented wearing a head-dress corresponding to the description of the $t \bar{a} j$. 
Isma'īl-like his father, Yusuf 'Ādil Shāh-was a Shī'ah ; but his father was a tolerant one, and Isma'īl extremely bigoted. The prime minister, Kamāl Khān, was a Sunnī, and whilst he held the reins of government during the minority of Isma'il, he restored the Sunni faith; but when Isma'îl, after the assassination of Kamāl Khān, assumed the government himself, one of his first acts was to re-introduce the Shĩah religion; and it was in connection with this that he ordered the wearing of the red $t \bar{a} j$ of twelve points, doubtless symbolical of the twelve Imāms. Shāh Isma‘îl Safavì and Isma‘il 'Ādil Shāh were contemporaries, and the former sent an embassy to the Court of the latter.-Yours faithfully,

To the Secretary of the Royal Asiatic Society.

$$
\text { J. S. KING (Major). }
$$

\section{Parsee Punchayet.}

131, Hornby Road, Bombay, March 6, 1896.

To the President of the Royal Asiatic Society, London.

Sir,-I am directed by the Trustees of the Parsee Punchayet to request you to be good enough to bring the following matter to the notice of your Oriental scholars travelling through and taking interest in Central Asia.

You know that the regions of Central Asia were once either inhabited by the ancient Zoroastrians, or were under their direct or indirect influence. So the Parsees, or the modern Zoroastrians, being the descendants of those ancient Zoroastrians, take an interest in these regions. They would welcome any information obtained in these regions that would throw some light on their ancient literature and on the manners, customs, and history of their ancient fatherland of Iran. If your scholars and travellers will put themselves in literary communication in English with us, their contribution on these subjects will be very gratefully received. The Trustees will be glad to patronize any publication in English treating of the researches in these 